\title{
Cableia pudica n. Sp. (Digenea: Acanthocolpidae) FROM MONACANTHID FISHES Of the southern Great Barrier Reef, Australia
}

\author{
BRAY R.A.*, CRIBB T.H.** \& BARKER S.C.***
}

\begin{abstract}
Summary:
A new species, Cableia pudica, is described from the monacanthid fishes Cantheschenia grandisquamis, Cantherhines dumerili, Cantherhines pardalis and Pervagor janthinosoma from reef waters around Heron Island, southern Great Barrier Reef, Queensland, Australia. It differs from the only other species in the genus, Cableia trigoni Sogandares-Bernal, 1959 in its more elongate cirrus-sac, longer post-testicular region, smaller prepharynx, the less anterior extent of the vitelline fields and dorsally subterminal excretory pore. The status of the genus is discussed, but no firm conclusion reached. It is placed, pro tem. in the Acanthocolpidae. The great majority of specimens lack spermatozoa, suggesting that parthenogenesis may occur.
\end{abstract}

KEY WORDS : Acanthocolpidae, Cableia, Monacanthidae, Cantheschenia, Cantherhines, Pervagor, Great Barrier Reef, systematics, parthenogenesis.

\section{INTRODUCTION}

T he systematics of the Digenea is not well developed, and their phylogeny is poorly understood. It is still possible to come across worms whose relationships are difficult to decipher, and which exhibit puzzling combinations of characters. Cableia Sogandares-Bernal, 1959 is such a genus. Although we describe a new species below, the familial affinities of the genus are still enigmatic. If our morphological interpretations are correct, its relationship to some of the families to which it has been assigned can be considered doubtful.

\footnotetext{
* Department of Zoology, The Natural History Museum, Cromwell Road, London SW7 5BD, UK.

** Department of Parasitology, The University of Queensland, Brisbane, Queensland 4072, Australia.

*** Department of Parasitology and Centre for Molecular and Cellular Biology, The University of Queensland, Brisbane, Queensland 4072, Australia.

Correspondence: Dr R.A. Bray. Tel.: 0171-938-9492. Fax: 0171-938-

8754. e-mail r.bray@nhm.ac.uk
}

Résumé : CABLEIA PUDICA N, SP. (DigenEa: ACANTHOCOLPIDAE) DÉCRITE DES POISSONS MONACANTIDÉS DE LA PARTIE SUD DE LA Grande Barrière de Corail, Australif

Cableia pudica n. sp. est décrite des poissons monacantidés Cantheschenia grandisquamis, Cantherhines dumerili, Cantherhines pardalis et Pervagor janthinosoma de la zone corallienne entourant Heron Island, dans la partie sud de la Grande Barrière de Corail (Queensland, Australia). Elle diffère de Cableia trigoni Sogandares-Bernal, 1959, seule autre espèce connue du genre, en ce qu'elle présente une poche du cirre plus allongée, une région post-testiculaire plus longue, un pré-pharynx plus petit, une bordure antérieure des champs vitellins plus postérieure et un pore excréteur dorsal et subterminal. Le statut du genre est discuté, mais aucune conclusion définitive n'est atteinte. Il est provisoirement placé parmi les Acanthocolpidae. La grande majorité des spécimens ne présente pas de spermatozoïdes, ce qui suggère une possible reproduction parthénogénétique.

MOTS CLÉS : Acanthocolpidae, Cableia, Monacanthidae, Cantheschenia, Cantherhines, Pervagor, Grande Barrière de Corail, systématique, parthénogénèse.

\section{MATERIALS AND METHODS}

he digeneans were collected from freshly killed fish and were fixed by being pipetted into nearly boiling $5 \%$ formalin. Whole-mounts were stained with Mayer's acid haemalum, cleared in methyl salicylate and mounted in Canada balsam. Serial sections were stained in eosin and Mayer's haemalum. Measurements are quoted as ranges, with means in parentheses, and are in micrometres. The following abbreviations are used: $\mathrm{BM}(\mathrm{NH})$, the British Museum (Natural History) collection at The Natural History Museum, London; QM, Queensland Museum collection, Brisbane; USNPC, the United States National Parasite Collection, Beltsville.

\section{MATERIAL STUDIED}

Ex Cantheschenia grandisquamis Hutchins (type-host), Monacanthidae. Intestine. Heron Island, Queensland, Australia $\left(23^{\circ} 27^{\prime} \mathrm{S}, 150^{\circ} 55^{\prime} \mathrm{E}\right.$ (type-locality), between 9 and 24/1/1992, 15/1/1994, 6/7/1995); 17 specimens (also two sets of serial sections). QM holotype 211573 , paratypes 211574-9, BM(NH) paratypes 1995.7.4.1-5. 
Ex Cantherhines pardalis (Rüppell), Monacanthidae. Intestine. Heron Island, Queensland, Australia (2327's, 150 ${ }^{\circ} 55^{\prime} \mathrm{E}, 24 / 1 / 1992$, between 14 and 21/1/1994). 37 specimens (also one set of serial sections). QM 211580-90, BM(NH) 1995.7.4.6-15.

Ex Cantherhines dumerili.(Hollard), Monacanthidae. Intestine. Heron Island, Queensland, Australia ( $23^{\circ} 27^{\prime}$ 'S, 15055'E, 15/1/1992). Two specimens. QM 211591, $\mathrm{BM}(\mathrm{NH})$ 1995.7.4.16.

Ex Pervagor janthinosoma (Bleeker), Monacanthidae. Intestine. Heron Island, Queensland, Australia ( $23^{\circ} 27^{\prime}$ S, $\left.150^{\circ} 55^{\prime} \mathrm{E}, 13 / 1 / 1991\right)$. Four specimens. QM 211592-3, $\mathrm{BM}(\mathrm{NH})$ 1995.7.4.17.

\section{RESULTS}

$\mathrm{F}$ amily Acanthocolpidae Lühe, 1909.

Genus Cableia Sogandares-Bernal, 1959.

Type-species C. trigoni Sogandares-Bernal, 1959 by original designation.

CABLEIA PUDICA N. SP. (Figs 1-3)

\section{DESCRIPTION}

Based on 65 whole-mounts and three sets of serial sections. For measurements see Table I. Body small, elongate but slightly wider at ventral sucker and testicular levels (Fig. 1). Tegument spinous; spines in closely packed rows, largest in anterior hindbody, become sparser at about testicular level and disappear about middle of post-testicular region. Eye-spot pigment scattered sparsely in forebody. Oral sucker subglobular, subterminal. Ventral sucker subglobular on short peduncle, which appears as ridge around ventral sucker in ventral view. Prepharynx distinct, but mainly within posterior concavity of oral sucker; measurement of exposed part only given in Table I. Pharynx subglobular. Oesophagus sigmoid. Intestinal bifurcation in posterior forebody. Caeca widest anteriorly, narrow for most of length, terminate blindly at about middle of post-testicular region, often not symmetrically.

Testes oval, posterior testis longer than anterior, tandem, contiguous, in mid-hindbody. External seminal vesicle absent, coiled vas deferens can be traced to cirrus-sac. Cirrus-sac long, reaching to or almost to ovary, recurved dorsally to ventral sucker (Fig. 2). Internal seminal vesicle with two oval chambers, narrows distally to form curved muscular duct; spermatozoa rarely seen (Fig. 3). Pars prostatica vesicular, small, oval; lined with anuclear cell-like bodies. Ejaculatory duct long, coiled, muscular; cirrus not seen. Prostatic gland-cells scattered rather sparsely in connective tissue in cirrus-sac. Genital atrium distinct. Genital pore slightly sinistrally submedian at level of intestinal bifurcation.
Ovary usually four-lobed (occasionally appears three to six-lobed); separated from ventral sucker by uterus, contiguous with anterior testis; median. Uterine seminal receptacle present. Mehlis' gland antero-dorsal to ovary. Laurer's canal opens dorsally to ovary. Uterus between ovary and ventral sucker, overlaps caeca laterally. Eggs small; numerous; operculate, tanned. Metraterm muscular, starts about mid-ventral sucker, runs ventrally to cirrus-sac, opens beside male duct into genital atrium. Vitellarium follicular; follicles many, relatively large, irregular; lateral fields reach from just anterior to ovary to point posterior to caecal terminations, but not close to posterior extremity; dorsal, lateral and ventral to caeca at level of gonads; confluent dorsally and ventrally in post-testicular region.

Excretory pore distinctly dorsally subterminal. Vesicle I-shaped; reaches just posterior to posterior testis.

\section{DISCUSSION}

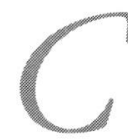

ableia was originally considered to belong in the Lepocreadiidae Odhner, 1905 by Sogandares-Bernal (1959). It was subsequently placed in the Opecoelidae Ozaki, 1925 by Yamaguti (1971). The most recent placement of the genus is in the Enenteridae Yamaguti, 1958 by Gibson \& Bray (1982). The lack of both the external seminal vesicle and the canalicular seminal receptacle, along with the presence of small eggs are certainly uncharacteristic of lepocreadiids, and the spinous tegument, the eyespot pigment and the small eggs are not characteristic for opecoelids.

The subfamily Enenterinae was erected by Yamaguti (1958) as a subfamily of the Allocreadiidae to include three genera, Enenterum Linton, 1910, Cadenatella Dollfus, 1946 and Jeancadenatia Dollfus, 1946. Later, Yamaguti (1970, 1971) placed the subfamily in the Opecoelidae, including the same three genera. In the meantime Skrjabin \& Koval (1966) had recognised the family Enenteridae, including two additional genera, Koseiria Nagaty, 1942 and Proenenterum Manter, 1954. Bray (1978) summarised the history of the family to that time, pointing out that its members had characters of both the Lepocreadiidae and the Opecoelidae, and retained the family pro tem. He also pointed out that it could readily be divided into two parts, which might represent subfamilies, applying the reasoning used to separate the opecoelid subfamilies Opecoelinae and Plagioporinae Manter, 1947. Later, Gibson \& Bray (1982) formally named the second subfamily as the Cadenatellinae. They also argued for inclusion of a third subfamily, the Pseudolepidapedinae Yamaguti, 1971, with two genera Pseudolepidapedon Yamaguti, 1938 and Cableia Sogandares-Bernal, 1959, members 

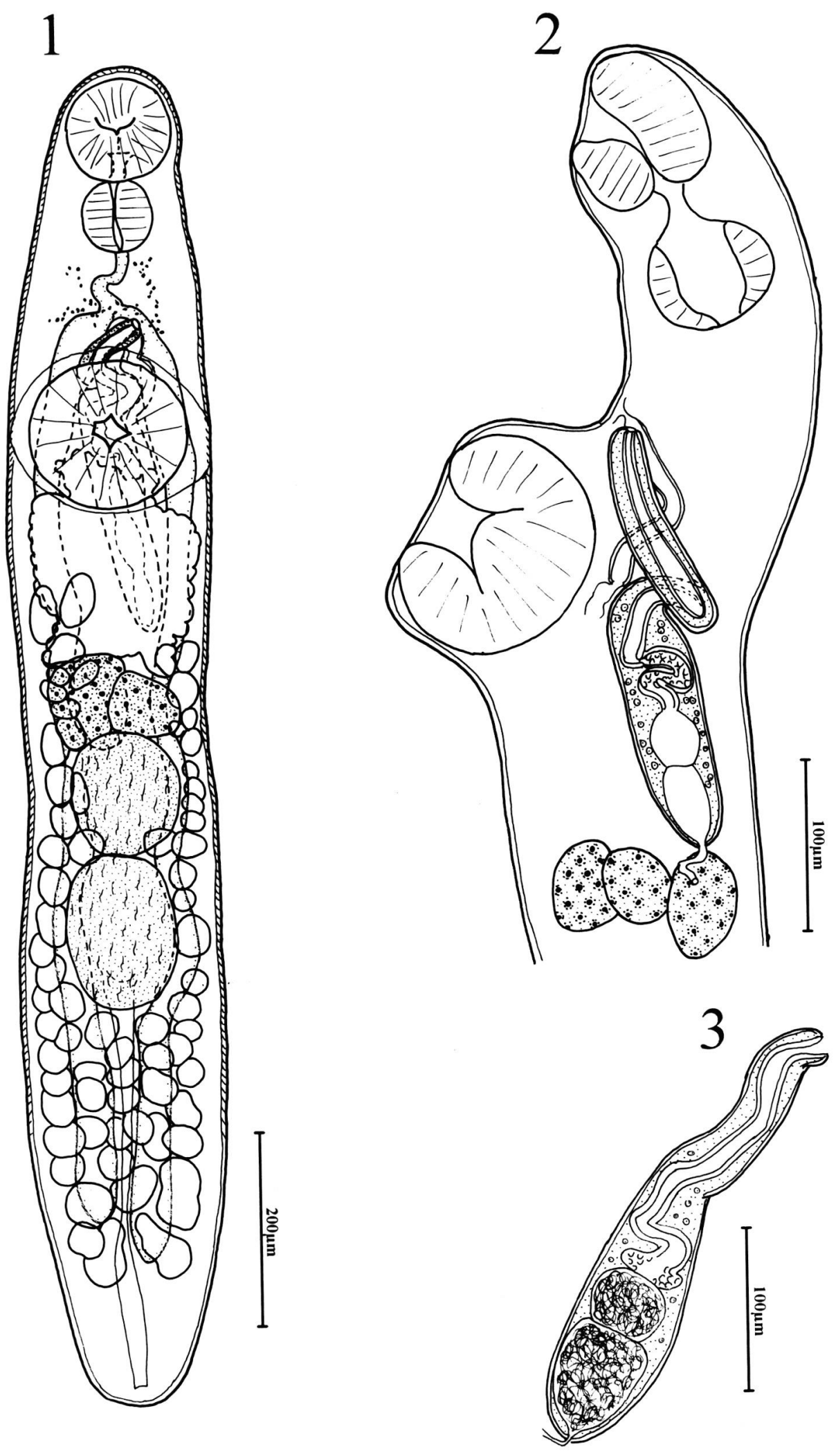

Figs 1-3. - Cableia pudica n. sp. 1. Ventral view of specimen from Cantheschenia grandisquamis, uterus in outline only. 2. Lateral view of anterior half of specimen from Cantheschenia grandisquamis, showing terminal genitalia and lack of spermatozoa in internal seminal vesicle. 3. Cirrus-sac from specimen from Cantherhines pardalis, showing spermatozoa in internal seminal vesicle. 


\begin{tabular}{|c|c|c|c|c|}
\hline $\begin{array}{c}\text { Host } \\
n\end{array}$ & $\begin{array}{c}\text { Cantheschenia } \\
\text { grandisquamis } \\
10\end{array}$ & $\begin{array}{c}\text { Cantherbines } \\
\text { dumerili } \\
1\end{array}$ & $\begin{array}{c}\text { Cantherbines } \\
\text { pardalis } \\
10\end{array}$ & $\begin{array}{c}\text { Pervagor } \\
\text { janthinosoma } \\
2\end{array}$ \\
\hline Body length & $989-1,407(1,254)$ & 1,081 & $808-1,619(1,348)$ & $599-654$ \\
\hline Body width & $175-255(224)$ & 260 & $172-303(241)$ & $127-143$ \\
\hline Width/length (\%) & 16-22 (18) & 24 & $16-23(18)$ & $19-24$ \\
\hline Oral sucker & $\begin{array}{c}95-130 \times 98-129 \\
(110 \times 113)\end{array}$ & $117 \times 118$ & $\begin{array}{c}97-137 \times 91-148 \\
(120 \times 127)\end{array}$ & $73-76 \times 69-70$ \\
\hline Ventral sucker & $\begin{array}{l}127-180 \times 140-187 \\
(160 \times 165)\end{array}$ & $161 \times 173$ & $\begin{array}{c}122-206 \times 135-207 \\
(172 \times 184)\end{array}$ & $99-117 \times 96-108$ \\
\hline Sucker ratio & $1: 1.36-1.50(1.45)$ & $1: 1.47$ & $1: 1.34-1.54(1.45)$ & $1: 1.37-1.57$ \\
\hline Forebody & 218-316 (274) & 254 & 191-341 (284) & $180-191$ \\
\hline $\begin{array}{l}\text { Forebody/body } \\
\text { length }(\%)\end{array}$ & $20-23(21)$ & 23 & $20-25(21)$ & $29-30$ \\
\hline Prepharynx length & $0-16(3)$ & 0 & 0 & 0 \\
\hline Pharynx & $\begin{array}{c}54-85 \times 60-84 \\
(75 \times 73)\end{array}$ & $71 \times 76$ & $\begin{array}{l}55-93 \times 60-89 \\
(82 \times 77)\end{array}$ & $45-50 \times 38-43$ \\
\hline $\begin{array}{l}\text { Oral sucker/pharynx } \\
\text { width ratio }\end{array}$ & $1: 1.31-1.77(1.55)$ & $1: 1.55$ & $1: 1.52-1.82(1.64)$ & $1: 1.60-1.84$ \\
\hline Oesophagus length & $26-58(48)$ & 77 & $26-74(48)$ & $20-38$ \\
\hline $\begin{array}{l}\text { Intestinal bifurcation } \\
\text { to ventral sucker }\end{array}$ & $19-68(45)$ & 0 & $14-71(49)$ & $33-41$ \\
\hline $\begin{array}{l}\text { Caecal ends to } \\
\text { posterior extremity }\end{array}$ & $87-187(143)$ & $?$ & $64-224(133)$ & $51-66$ \\
\hline Anterior testis & $\begin{array}{c}89-148 \times 99-142 \\
(123 \times 122)\end{array}$ & $78 \times 95$ & $\begin{array}{c}71-149 \times 81-179 \\
(119 \times 125)\end{array}$ & $52-53 \times 50-51$ \\
\hline Posterior testis & $\begin{array}{l}113-200 \times 111-148 \\
(161 \times 131)\end{array}$ & $90 \times 103$ & $\begin{array}{c}98-219 \times 86-187 \\
(170 \times 126)\end{array}$ & $72-75 \times 48-51$ \\
\hline Post-testicular region & 234-444 (362) & 303 & $161-425(352)$ & $122-147$ \\
\hline $\begin{array}{l}\text { Post-testicular region/ } \\
\text { body length }(\%)\end{array}$ & $24-32(29)$ & 28 & $20-30(26)$ & $20-22$ \\
\hline Cirrus-sac & $\begin{array}{l}290-322 \times 48-58 \\
(308 \times 51)\end{array}$ & $?$ & $\begin{array}{c}261-406 \times 32-64 \\
(349 \times 60)\end{array}$ & $207 \times ?$ \\
\hline Ventral sucker to ovary & $71-167$ (126) & 158 & 87-261 (188) & $45-79$ \\
\hline Ovary & $\begin{array}{c}64-113 \times 89-151 \\
(95 \times 123)\end{array}$ & $93 \times 144$ & $\begin{array}{c}55-129 \times 70-174 \\
(106 \times 167)\end{array}$ & $41-47 \times 47-57$ \\
\hline Eggs & $\begin{array}{c}28-3213-18 \\
(30 \times 16)\end{array}$ & $27-29 \times 16-17$ & $\begin{array}{c}29-33 \times 14-16 \\
(30 \times 16)\end{array}$ & $29-35 \times 13-16$ \\
\hline
\end{tabular}

Table I. - Measurements of Cableia pudica n. sp.

of which possess an uterine seminal receptacle and a large cirrus-sac. The list of constituent genera of the Enenteridae they mentioned was considered by them to for a 'convenient phenetic, rather than a phyletic assemblage'. One of the genera they listed, namely Neophasis Stafford, 1904, has since been discussed in detail by Bray \& Gibson (1991) and considered an aberrant acanthocolpid, taking into account life-cycle, larval and adult characters. Bray \& Gibson's (1991) observations of several Neophasis species showed that, in contradiction to several previous descriptions, where a seminal receptacle could be traced it was of the uterine type. Gibson \& Bray (1982) had placed Neophasis in the Enenterinae, which differs from the Pseudolepidapedinae in possessing a canalicular seminal receptacle (see Gibson \& Bray, 1979, for definitions of the seminal receptacle types) so, clearly, Neophasis was wrongly designated at this stage. Now that Neophasis is considered an aberrant acanthocolpid, it calls into question the status of the genera placed in the Pseudolepidapedinae by Bray \& Gibson (1991). Pseudolepidapedon, which has ten described species, was considered an acanthocolpid genus by Skrjabin (1954). Indeed, eight of the described species ( $P$. paralichthydis Yamaguti, 1938, P. balistis Manter, 1940, P. kobayashii Yamaguti, 1938, P. lethrini Yamaguti, 1952, P. mordvinovae Parukhin, 1978, P. pudens (Linton, 1900), P. sinaloense Bravo-Hollis, 1956 and P. laticaecale Reimer, 1981) have an overall morphology and particularly an alimentary system (long prepharynx, large pharynx, very short oesophagus) which is markedly similar to that of a typical acanthocolpid. The ninth described species, P. indica Gupta \& Ahmad, 1976, has its genital pore posterior to the aperture of the ventral sucker (Gupta \& Ahmad, 1976), and clearly belongs in another genus. The most recently 
described species, $P$. hydrolagi Machida \& Kuramochi, 1994 (described from the holocephalan Hydrolagus mitsukurii), is said to lack both a seminal receptacle and an external seminal vesicle, so its inclusion in the Lepocreadiidae by Machida \& Kuramochi (1994) must be questionable, but its alimentary system is not markedly acanthocolpid-like. Cableia does not have the same superficial similarity to the typical acanthocolpid as is the case for most species of Pseudolepidapedon and, with its small eggs, it does not fit comfortably into the Enenteridae, Lepocreadiidae, Acanthocolpidae or Opecoelidae. A bipartite internal seminal vesicle as found in Cableia is rarely found in the Opecoelidae, Lepocreadiidae and Enenteridae, but is said to occur in some acanthocolpid genera, including Stephanostomum Looss, 1899 [see, e. g., S. microstephanum Manter, 1934 according to Manter (1934), Fig. 40], Tormopsolus Poche, 1925 [see, e. g., T. osculatus (Looss, 1901) according to Looss (1901), Fig. 11], and Neophasis [see, e. g., N. osculatus (Levinsen, 1881) according to Bray \& Gibson (1991), Fig. 5]. The lack of an external seminal vesicle and the presence of an uterine seminal receptacle in Cableia precludes its inclusion in the Lepocreadiidae (sensu Gibson \& Bray, 1982) and the spinous tegument precludes its inclusion in the Opecoelidae. If Pseudolepidapedon is, in fact, considered an acanthocolpid, Cableia is left as a genus incertae sedis, with claims to both enenterid and acanthocolpid affinities. Clearly a knowledge of lifecycle or larval information, or molecular phylogenetic studies, are needed to shed more light on the status of this form, but we believe that the Acanthocolpidae should act as a repository pro tem. The subfamily Pseudolepidapedinae is, therefore, subsumed into the family Acanthocolpidae. Whether it should retain its subfamily status is doubtful, and would need a revision of the family to ascertain. It does not appear that Pseudolepidapedon and Cableia are particularly closely related.

These specimens are considered to belong in Cableia because of the lobate ovary and the small eggs, but differ from the type- and only species, C. trigoni Sogandares-Bernal, 1959, based on a single specimen from Lactophrys trigonus [Ostraciidae], Bimini, West Indies, in possessing a more elongate cirrus-sac, a longer post-testicular region, a shorter prepharynx, vitelline fields less extensive anteriorly and a dorsally subterminal excretory pore. Sogandares-Bernal (1959) described a uroproct, but Yamaguti's (1971) re-examination showed that the caeca terminate blindly at different levels (see his fig. 403). In our examination of the holotype (USNPC 38864), we were not able to confirm all of Yamaguti's findings. We agree that the right caecum appears to terminate blindly at the level of the anterior part of the posterior testis, but we cannot clearly distinguish the termination of the left caecum. It appears that the left caecum is long and may be extruded through the excretory pore (presumably during flattening) as a small globular body (see Sogandares-Bernal's figure - this feature is omitted from Yamaguti's figure). The detail is far from clear, but we can see no real evidence for a uroproct.

The definition of Cableia given by Yamaguti (1971) may be supplemented by the following statements: oesophagus short to long. Testes in mid- to posterior hindbody. Cirrus finely spined or not.

A striking characteristic of most of these specimens, from all four hosts, is that there is no sign of spermatozoa, in either internal or external seminal vesicles or the proximal uterus, nor is there is any indication of spermatogenesis in the testes. Bray (1987) found a similar condition in the zoogonid Steganoderma (S.) formosum Stafford, 1904 in part of its geographical range and suggested, in line with observations discussed in Whitfield \& Evans (1983), that this indicated parthenogenesis. However, in three specimens (of five) from the same host specimen of Cantheschenia grandisquamis and four specimens (of 13) from the same host specimen of Cantherhines pardalis, spermatozoa were seen in the bipartite internal seminal vesicle and there was evidence of spermatogenesis in the testes. In several of these specimens sperm was accumulated in the proximal sling of the uterus. In these specimens there was no evidence of an external seminal vesicle. Cableia was described as having a "club-shaped seminal receptacle" by Sogandares-Bernal (1959), but Yamaguti (1971) re-examined and redrew the type showing "receptaculum seminis uterinum conspicuous, but no true seminal receptacle". Examination of the holotype confirms Yamaguti's findings.

The name pudica (Latin: modest, chaste, virtuous) refers to the apparent infrequency of normal sexual activity in these worms.

\section{ACKNOWLEDGEMENTS}

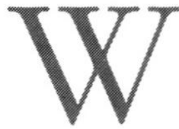
e thank Rob Adlard, Glenn Anderson, Helena Hall and Trudy Wright of The University of Queensland and Vicki Sands of The Queensland Museum for assistance with the collection and preparation of the material described in this paper, and Dave Cooper for the preparation of serial sections. We are grateful to Dr. J.R. Lichtenfels, US National Parasite Collection, Beltsville, Maryland, USA for lending material. The work was supported by a Queen Elizabeth II fellowship to THC, an ARC National Research Fellowship to SCB, an ARC grant A19031169 to THC and SCB, a University of Queensland Special Project Grant to SCB, a University of Queensland 
Travel Grant to RAB, an ABRS grant to THC, and the Heron Island Research Station. Dr. David Gibson, NHM, London, critically reviewed the manuscript. Dr. Jean Mariaux, Université de Neuchâtel, Switzerland, kindly translated the summary.

\section{REFERENCES}

BRAY R.A. Two new species of Enenterum Linton, 1910 (Digenea) in the marine fish Neoscorpis lithophilus (Kyphosidae) from the south-western Indian Ocean. Journal of Helmintbology, 1978, 52, 131-139.

BRAY R.A. A revision of the family Zoogonidae Odhner, 1902 (Platyhelminthes: Digenea): Subfamily Lepidophyllinae and comments on some aspects of biology. Systematic Parasitology, 1987, 9, 83-123.

BrAY R.A. \& GiBSON D.I. The Acanthocolpidae (Digenea) of fishes from the north-east Atlantic: the status of Neophasis Stafford, 1904 (Digenea) and a study of North Atlantic forms. Systematic Parasitology, 1991, 19, 95-117.

GiBSON D.I. \& BRAY R.A. The Hemiuroidea: terminology, systematics and evolution. Bulletin of the British Museum (Natural History) (Zoology series), 1979, 36, 35-146.

GIBSON D.I. \& BRAY R.A. A study and reorganization of Plagioporus Stafford, 1904 (Digenea: Opecoelidae) and related genera, with special reference to forms from European Atlantic waters. Journal of Natural History, 1982, 16, 529559.

Gupta V. \& Ahmad J. Digenetic trematodes of marine fishes. On four new species of trematodes of marine fishes of Puri, India. Rivista di Parassitologia, 1976, 37, 133-142.

Looss A. Ueber die Fasciolidengenera Stephanochasmus, Acanthochasmus und einige andere. (Schluß). Centralblatt für Bakteriologie, Parasitenkunde und Infektionskrankheiten, 1901, 29, 654-661.

Machida M. \& Kuramochi T. Two new species of trematodes (Gorgoderidae and Lepocreadiidae) from deep-sea fishes of Suruga Bay, Japan. Bulletin of the National Science Museum, Tokyo, Series A, 1994, 20, 149-153.

MANTER H.W. Some digenetic trematodes from deep-water fish of Tortugas, Florida. Papers from Tortugas Laboratory, 1934, 28, 257-346.

SkrJabIN K.I. [Family Acanthocolpidae Lühe, 1909]. Trematody Zhivotnykh $i$ Cheloveka. Osnovy Trematodologii, 1954, 9, 45-224 (in Russian).

SKrJabin K.I. \& Koval V.P. [Family Enenteridae Skrjabin et Koval, 1965]. Trematody Zhivotnykh i Cheloveka. Osnovy Trematodologii, 1966, 22, 477-506 (in Russian).

Sogandares-Bernal F. Digenetic trematodes of marine fishes from the Gulf of Panama and Bimini, British West Indies. Tulane Studies in Zoology, 1959, 7, 69-117.

Whitfield P.J. \& Evans N.A. Parthenogenesis and asexual multiplication among parasitic platyhelminths. (Symposia of the British Society for Parasitology, Vol. 20. Whitfield, P.J. (Ed.) The reproductive biology of parasites). Parasitology, 1983, 86 (4 supplement), 121-160.
YAMAGUTI S. Systema helminthum. Vol. 1. The digenetic trematodes of vertebrates. Interscience, New York, 1958, 1,575 p.

YAMAGUTI S. The digenetic trematodes of Hawaiian fishes. Keigaku, Tokyo, 1970, $436 \mathrm{p}$.

YAMAGUTI S. Synopsis of digenetic trematodes of vertebrates. Keigaku, Tokyo, Vols 1 and 2, 1971, 1,074 p, 349 pls.

Reçu le 18 juillet 1995 Accepté le 25 septembre 1995 